\title{
Surgical treatment of isolated coarctation of the aorta: 18 years' experience
}

\author{
P RAJ BEHL, P SANTÉ, A BLESOVSKY
}

From the Department of Cardiothoracic Surgery, Regional Cardiothoracic Centre, Freeman Hospital, Newcastle upon Tyne

ABSTRACT From March 1967 to February 198591 patients aged from 11 months to 53 years underwent surgical treatment of isolated coarctation of the aorta. The surgical procedures in descending order of frequency, were: resection with end to end anastomosis, resection with replacement by a tube graft, patch aortoplasty, and bypass graft. Resection with end to end anastomosis was achieved mainly in younger patients. The number of patients needing other procedures increased with advancing age. Eighty six patients have been followed up (mean 10 years). There were no hospital or late deaths and none of the patients suffered from spinal cord injury. There were three recurrences of the coarctation, all in patients who had had primary reconstruction below the age of one year. The patients were divided into three groups by age: group 1,0-5 years; group 2, 6-15 years; and group 3, over 15 years. It was found that there was no late hypertension in group 1 while hypertension persisted in $7 \%$ of group 2 and in $28 \%$ of group 3 . Fifty per cent of the patients with persistent hypertension were above the age of 20 years at the time of operation and had resection with replacement by a tube graft. It is recommended that elective surgery for coarctation of the aorta should be performed at the age of 3-5 years to avoid both recurrence of stenosis and persistent hypertension.

Coarctation of the aorta was first described by Morgagni in $1760^{1}$ but was not surgically corrected until 1945, when resection with end to end anastomosis was achieved. ${ }^{23}$ Since that time several other procedures have been described ${ }^{4-9}$ and surgical correction is now established as the treatment of choice. While there is general agreement about the necessity for urgent operation in coarctation with heart failure,${ }^{10}$ or with severe upper limb hypertension, controversy still exists regarding the optimal age for treatment of the relatively symptom free patient.

This study describes the outcome in 91 patients who underwent corrective surgery for isolated coarctation of the aorta in the course of 18 years, with a mean follow up of 10 years after operation. The purpose of the study was to determine the frequency of raised systemic blood pressure after operation and to study its relationship with age at operation and the type of operation performed.

Address for reprint requests: Mr P Raj Behl, Department of Cardiothoracic Surgery, Freeman Hospital, Newcastle upon Tyne, NE7 7DN.

Accepted 29 September 1986

\section{Methods}

\section{PATIENTS}

From March 1967 to February 198591 patients were admitted under the care of one surgeon (AB) for surgical treatment of isolated coarctation of the aorta at the Shotley Bridge General and Freeman Hospitals. Ninety one patients ( 36 female and 55 male) underwent 93 operations; two patients each had two operations, and another, who had had primary correction at the age of 11 months at another centre, was reoperated in our unit when he was 18 years old.

The indication for operation was the presence of coarctation with or without upper limb hypertension. During 1967-74 only three patients under the age of 1 year were referred for surgery, reflecting the conservative approach of the cardiologists. Since then, opinion has changed and the emphasis has shifted towards surgery; the patients under 1 year of age were, however, referred to another surgical firm. Only two patients have been excluded from this series. One patient had a true and the other a false aneurysm of the aorta distal to the coarctation that followed bacterial endocarditis, and both these patients were treated successfully by resection with graft replacement. 
Table 1 Preoperative physical findings

\begin{tabular}{|c|c|c|c|c|}
\hline \multirow[b]{2}{*}{ Variable } & \multicolumn{3}{|c|}{ Group and age (y) } & \multirow[b]{2}{*}{$\begin{array}{l}\text { Total } \\
\text { group } \\
(n=91\end{array}$} \\
\hline & $\begin{array}{l}l \\
0-5 \\
(n=20)\end{array}$ & $\begin{array}{l}2 \\
6-15 \\
(n=43)\end{array}$ & $\begin{array}{l}3 \\
>15 \\
(n=28)\end{array}$ & \\
\hline \multicolumn{5}{|l|}{$\begin{array}{l}\text { Arm-leg blood } \\
\text { pressure }>\end{array}$} \\
\hline $30 \mathrm{~mm} \mathrm{Hg}$ & 16 & 30 & 19 & 65 \\
\hline Systolic murmur & 20 & 43 & 28 & 91 \\
\hline $\begin{array}{l}\text { Decreased femoral } \\
\text { pulses }\end{array}$ & 20 & 43 & 26 & 89 \\
\hline $\begin{array}{l}\text { Palpable intercostals } \\
\text { Posterior chest wall }\end{array}$ & 2 & 11 & 9 & 22 \\
\hline $\begin{array}{c}\text { murmur } \\
\text { Hypertension }\end{array}$ & $\begin{array}{r}8 \\
12\end{array}$ & $\begin{array}{l}14 \\
28\end{array}$ & $\begin{array}{l}19 \\
25\end{array}$ & $\begin{array}{l}41 \\
65\end{array}$ \\
\hline
\end{tabular}

The 91 patients ranged in age from 11 months to 53 years. For the purpose of this study they were subdivided into three groups: group 1, 0-5 years (20 patients $(22 \%$ of the total)); group 2, 6-15 years (43 patients $(47 \%)$ ); and group 3, over 15 years (28 patients $(31 \%))$. The physical findings in each group are summarised in table 1 .

\section{ASSOCIATED LESIONS}

Among the associated lesions, bicuspid aortic valve was observed in $40 \%$ of the patients, patent ductus arteriosus in $8 \%$, a small ventricular septal defect in $3 \%$, and aneurysms of the intercostal arteries in $12 \%$.

\section{INVESTIGATIONS}

Radiological examination of the chest and electrocardiography were performed in each patient, and 54 had cardiac catheterisation (table 2). Echo cardiography was performed in the last few patient $\stackrel{\text { ? }}{?}$ The systolic pressure gradient across the coarctation in each of the three groups was 20-110, 20-75, an $25-100$, with means of 50,45 , and $60 \mathrm{~mm} \mathrm{Hg}$ res spectively (table 2 ).

\section{SURGICAL TECHNIQUE}

Most $(80 \%)$ of the patients in groups 1 and 2 and $45 \%$ in group 3 had resection with end to end anase tomosis (table 3). Among these, two patients in grou 2 also had reimplantation of the left subclavian a tery. The next most common operation, mainly group 3, $(41 \%)$, was resection with interposition of tube graft, with reimplantation of the left subclaviate artery in one patient. This procedure was performed in only three $(7 \%)$ of the patients in group 2 and none in group 1. Patch grafts were used in 10 patients, three in group 1, five in group 2, and two in group In eight patients a poor collateral circulation was observed at operation. In all these patients a temporakg shunt of crimped Dacron tube was established bet tween the left subclavian artery and the aorta beyond the coarctation to prevent spinal cord damage. Afte the insertion of the shunt, however, it was found tha the relief of obstruction was satisfactory in three $p_{8}^{2}$ tients. Consequently the shunts in these three patien were not taken down. In another patient a simila bypass graft was used because of the noticeable adhe sions in the region of the coarctation from previous mediastinitis. Thus bypass grafts were used in fo patients, two each in groups 2 and 3.

Table 2 Preoperative data in the three age groups

\begin{tabular}{|c|c|c|c|c|c|}
\hline & Group $I(n=20)$ & Group $2(n=43)$ & Group $3(n=28)$ & Total $(n=91)$ & (\% of tot \\
\hline $\begin{array}{l}\text { Chest radiograph } \\
\text { Rib notching } \\
\text { Cardiomegaly } \\
\text { "3 sign"* }\end{array}$ & $\begin{array}{r}4 \\
17 \\
3\end{array}$ & $\begin{array}{r}19 \\
25 \\
8\end{array}$ & $\begin{array}{r}7 \\
12 \\
2\end{array}$ & $\begin{array}{l}30 \\
54 \\
13\end{array}$ & $\begin{array}{l}(32) \\
(59) \\
(14)\end{array}$ \\
\hline $\begin{array}{l}\text { Electrocardiogram } \\
\text { LVH } \\
\text { RVH } \\
\text { LVH + RVH } \\
\text { Normal }\end{array}$ & $\begin{array}{l}6 \\
4 \\
7 \\
3\end{array}$ & $\begin{array}{r}21 \\
4 \\
3 \\
15\end{array}$ & $\begin{array}{r}13 \\
1 \\
1 \\
13\end{array}$ & $\begin{array}{r}40 \\
9 \\
11 \\
31\end{array}$ & $\begin{array}{l}(43) \\
(10) \\
(12) \\
(34)\end{array}$ \\
\hline $\begin{array}{l}\text { Catheter } \\
\text { Number studied } \\
\text { Pressure gradient (systolic) }\end{array}$ & $20-110($ mean 50$)$ & 23 -75 (mean 45$)$ & $\begin{array}{l}17 \\
25-100(\text { mean } 60) \\
\end{array}$ & 54 & (59) \\
\hline \multicolumn{5}{|c|}{$\begin{array}{l}\text { *This refers to the appearance of the aortic shadow on the chest radiograph. } \\
\text { LVH, left ventricular hypertrophy; RVH, right ventricular hypertrophy. }\end{array}$} & 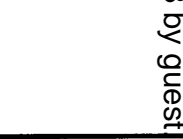 \\
\hline & Group I $(n=20)$ & Group $2(n=43)$ & Group $3(n=28)$ & Total & (\% of total) $\tau$ \\
\hline $\begin{array}{l}\text { Resection + EEA } \\
\text { Resection }+ \text { graft } \\
\text { Patch graft } \\
\text { Bypass graft } \\
\text { Total No of operations }\end{array}$ & $\frac{17}{3}$ & $\begin{array}{r}34 \\
3 \\
5 \\
2 \\
44\end{array}$ & $\begin{array}{r}13 \\
12 \\
2 \\
2 \\
29\end{array}$ & $\begin{array}{r}64 \\
15 \\
10 \\
4 \\
93^{*} \\
\end{array}$ & $\begin{array}{c}(68.8) \text { (RLSA: } \\
(16 \cdot 2) \text { (RLSA } \\
(10 \cdot 7) \\
(4 \cdot 3) \\
(100)\end{array}$ \\
\hline \multicolumn{5}{|c|}{$\begin{array}{l}\text { *Two patients each had two operations. } \\
\text { RLSA-reimplantation of left subclavian artery; EEA-end to end anastomosis. }\end{array}$} & ఏò \\
\hline
\end{tabular}


In patients under 1 year of age the anastomosis was completed with interrupted sutures, in patients aged 1-10 with continuous posterior and interrupted anterior layers, and over the age of 10 with continuous sutures. In the early part of the series Merselene sutures were used and in the latter part prolene sutures. From two to six intercostal arteries were divided and the aortic cross clamp time varied from 18 to 52 minutes (average 35 minutes).

\section{SYSTEMIC HYPERTENSION}

Like Lawrie et al, ${ }^{11}$ we defined blood pressure as normal if it was below $140 / 90 \mathrm{~mm} \mathrm{Hg}$. Mild hypertension was defined as ranging from $140 / 90$ to $160 / 100$ $\mathrm{mm} \mathrm{Hg}$ and severe hypertension as being above $160 / 110 \mathrm{~mm} \mathrm{Hg}$. In patients below 15 years we used the same three categories after applying the age adjusted criteria laid down by the Task Force on Blood Pressure Control in Children. ${ }^{12}$

\section{FOLLOW UP}

Eighty six patients have been followed up so far. This has been achieved either by seeing the patient or through correspondence. One patient emigrated and four others were lost to follow up. The follow up period ranged from six months to 18 years in group 1 , from eight months to 18 years in group 2 , and from one year to 16 years in group 3 (mean 10 years in each group). Resting blood pressures were recorded at each follow up attendance.

\section{Results}

\section{EARLY OUTCOME}

There were no deaths in hospital. Thirty three patients $(36 \%)$ - two in group 1,17 in group 2 , and 14 in group 3-had early complications (table 4).

\section{LATE OUTCOME}

\section{Mortality}

There was no death related to the surgical procedure or to the associated lesion. One patient, however, committed suicide one year after surgery.

\section{Neurological complications}

One patient in group 3 who was hypertensive suddenly developed left sided hemiplegia eight years after surgery. He made a slow but gradual recovery and at the last follow up visit he had minimal residual symptoms.

\section{Blood pressure response}

Of the 20 patients in group 1, two were lost to follow up. The remaining 18 were normotensive at the last attendance. In group 2, 15 were normotensive, 20 had mild hypertension, and the remaining eight had severe
Table 4 Early complications after surgery

\begin{tabular}{lc}
\hline & No of patients \\
\hline Paradoxical hypertension & 20 \\
Wound infection & 4 \\
Postoperative bleeding & 3 \\
Chylothorax & 3 \\
Transient leg paraesthesia & 1 \\
Abdominal pain & 1 \\
Subacute bacterial "endocarditis" & 1 \\
Total & $33(36 \%)$ \\
\hline
\end{tabular}

hypertension before surgery. After surgery 40 were normotensive and one was mildly and two severely hypertensive. In group 3,25 of the 28 patients were available for follow up. Before operation five had mild and 20 severe hypertension. At the time of the review, two had mild and five severe hypertension (table 5). Thus there were 10 patients in groups 2 and 3 who were still hypertensive. Five of these 10 were over 20 at the time of surgery. In these 10 patients with persistent hypertension resection with replacement by tube graft had been performed in five cases, resection with end to end anastomosis in three, and a bypass and a patch graft each in one case.

\section{RECURRENCE OF COARCTATION}

There were three recurrences of coarctation. All of these patients were 11 months old at the time of primary correction. Two patients had initially been operated on in our unit, while the third had his first operation at another centre (hence only 93 operations were performed in our centre). At the first operation two had resection with end to end anastomosis, while the third had a resection with tube graft interposition. At reoperation (when the patients were aged 9, 14, and 18 years) the surgical procedures were patch grafts in one and tube grafts in two cases.

\section{Discussion}

Simple coarctation leads to the development of hypertension proximal to the coarcted segment. The aetiology of this hypertension remains controversial, although several mechanisms have been suggested. ${ }^{13-16}$

If untreated, coarctation of the aorta decreases the life expectancy considerably. Campbell ${ }^{17}$ observed that $25 \%$ of those with untreated coarctation who survived the first two years of life died before the age of 20 years, $50 \%$ by $32,75 \%$ by 46 , and $90 \%$ by 58 years. These obvious risks led Lerberg et al ${ }^{18}$ to conclude that the absolute indication for surgery is the very existence of the coarctation itself, even though the patient is symptom free.

In our series 26 of $91(28.5 \%)$ patients were normotensive while $65(71.5 \%)$ were hypertensive before 
surgery. At the last follow up $88 \%$ were normotensive. There was thus an obvious benefit-which, however, was not uniformly spread in all three groups. All patients in group 1 were normotensive; but in group 2 three of $43(7 \%)$ patients and in group 3 seven of $25(28 \%)$ were hypertensive at follow up (table 5). These data suggest that the patients have a better chance of remaining normotensive when the elective operation is performed before the age of 5 .

The suggested optimal time for corrective surgery of coarctation of the aorta varies widely, though recent reports suggest an earlier age. ${ }^{1119}$ The results of the present study indicate that all patients operated on in group 1 and 40 of $43(93 \%)$ of the patients in group 2 had an excellent outcome in terms of hypertension (table 5). As 7\% of patients in group 2, however, had persistent hypertension, a proportion similar to the $9 \%$ reported by Bergdahl and associates, ${ }^{20}$ this would support our belief that operation should be considered below 5 years of age. In our older (group 3) patients, hypertension persisted in $28 \%$ of cases, compared with $37 \%$ and $46 \%$ in series reported by others. ${ }^{2021}$ This difference in the incidence of persistent hypertension is probably due to a longer follow up period in these other series. Clarkson and colleagues ${ }^{22}$ have clearly shown that the incidence of hypertension varies with the duration of the follow up and we therefore presume that more patients will become hypertensive with the passage of time.

Surgery for coarctation during the first year of life using end to end anastomosis, though advocated by some ${ }^{23}$ should be avoided if possible, because of the high risk of recurring stenosis and therefore recurring hypertension. ${ }^{24}$ This, however, contrasts with the results of aortic reconstruction using subclavian flap angioplasty. ${ }^{25}$ The incidence of persistent or recurrent pressure gradients after conventional repair of the coarctation of the aorta in infancy is around $33 \%$. ${ }^{2627}$ Beekman et $a l^{28}$ reported a $38 \%$ incidence of reoperation in patients younger than 3 years of age compared with $1.5 \%$ in patients over 3 . Moss and associates ${ }^{29}$ showed angiographically that by the age of 3 the ascending aorta had already grown to $55 \%$ of its adult diameter. The risk of recurring coarctation would therefore appear to be small when it is repaired after 3 years of age. A similar recommendation has been made by others. ${ }^{18}$ In our series there were three reoperations; all the children were 11 months old at the time of primary reconstruction. No other patient had a recurrence of coarctation of sufficient severity to warrant secondary corrective surgery. Therefore to remain normotensive and to avoid restenosis the surgery for uncomplicated coarctation should be performed before the age of 5 years and preferably after
Table 5 Late response of blood pressure to operation

\begin{tabular}{|c|c|c|c|c|c|c|}
\hline \multirow[b]{2}{*}{ Group } & \multicolumn{3}{|c|}{ Preoperative $(n=91)$} & \multicolumn{3}{|c|}{ 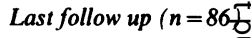 } \\
\hline & $N$ & $M$ & $S$ & $N$ & $M$ & $S$ \\
\hline $\begin{array}{l}1(n=20) \\
2(n=43) \\
3(n=28) \\
\text { Total No }(\%)\end{array}$ & $\begin{array}{c}8 \\
15 \\
3 \\
26(29)\end{array}$ & $\begin{array}{l}6 \\
20 \\
5 \\
31(34)\end{array}$ & $\begin{array}{l}6 \\
8 \\
20 \\
34(37)\end{array}$ & $\begin{array}{l}18 \\
40 \\
18 \\
76(88)\end{array}$ & $\begin{array}{l}0 \\
1 \\
2 \\
3(4)\end{array}$ & 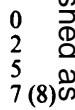 \\
\hline
\end{tabular}

$\mathrm{N}$, normotensive; $\mathrm{M}$, mild hypertension; $\mathrm{S}$, severe hypertension.

the age of 3 .

We were able to achieve resection with end to end anastomosis in 17 of the 20 procedures $(85 \%)$ pert formed in group 1 . The proportion fell to $77 \%$ if group 2 and to $45 \%$ in group 3 (table 3 ). The fre quency of graft interposition was significantly more frequent in group 3 patients: of the 29 patients in this group, $12(41 \%)$ had resection with graft replaceo ment, compared with three of $44(7 \%)$ procedures in group 2 ( $\mathrm{p}<0.001)$. Interestingly, five of the 10 pas tients who were hypertensive at the last follow up had tube grafts put in after resection of the coarcted sege ment (table 5). Three of the remaining five patient had resection with end to end anastomosis, one had bypass graft, and one a patch graft. Later in the serie patch grafting was avoided because of its reporte late complications. ${ }^{30}$ Evidently therefore not onl does the risk of needing a prosthetic graft increase with advancing age but there is also an added risk of hypertension either persisting or developing again. similar observation has been made by others, ${ }^{22}$ which substantiates our belief that surgery for coo arctation should be performed during early child hood, when a resection with end to end anastomosis can be achieved safely in most patients.

Percutaneous balloon angioplasty has been use for persistent or recurring coarctation after oper ation, ${ }^{32} 33$ though its role in unoperated patients has not yet been determined. ${ }^{34}$ Initial reductions in aortis gradients are observed to be followed by early recuro rence, ${ }^{34-36}$ and sometimes the procedure can be far tal. ${ }^{37}$ From his considerable experience Lock ${ }^{30}$ therefore cautions against an enthusiastic approacB for balloon angioplasty as the method of first choice्w

None of our patients had paraplegia after surgery? though its reported incidence varies from $0.5 \%$ t $1.5 \% .^{182239}$ We believe that if the coarctation is mil佸 with poor collateral vessels, resulting in a severe fall iff blood pressure in the distal segment after the aortad has been clamped, a temporary bypass shunt with $\Phi$ crimped dacron tube should be used. Other method $\$$ that have been recommended in patients with a ming imal collateral circulation are left atriofemoral bypase with a pump ${ }^{40}$ and the use of a heparin bonded shunt. ${ }^{41}$ 
There was only one late death (a patient committed suicide one year after operation). Another patient developed left sided hemiplegia eight years after surgery, but he recovered from it gradually. Clarkson et $a^{22}$ had 19 deaths two to 23 years after the operation, mainly due to cardiovascular diseases. Apparently therefore patients can develop fatal complications at varying times after surgery. The incidence will increase with the period of follow up, and it is thus essential that after corrective surgery for coarctation of the aorta, patients should be reviewed at regular intervals for early detection and management of complications arising either directly from the operation or from the associated lesions.

In conclusion, surgical correction of aorta in symptomless patients should preferably be performed at 3-5 years of age, so that both recurrence of stenosis and prolonged postoperative hypertension can be avoided and a resection with end to end anastomosis can be performed easily. In older patients the hypertension tends to be fixed and the frequency of prosthetic interposition with the likelihood of persisting hypertension increases. After surgery an indefinite follow up is essential.

We would like to thank Miss Carole Durkin for her assistance in the typing of this manuscript.

\section{References}

1 Morgagni JB. De sedibus et causis morborum. Epist XVIII, article 6. 1760. Quotes from Glenn WW, ed. Thoracic and cardiovascular surgery. 4th ed. Norwalk, Connecticut: Appleton-Century-Crofts, 1983: 813.

2 Crafoord C, Nylin G. Congenital coarctation of the aorta and its surgical treatment. $J$ Thorac Cardiovasc Surg 1945; 14:347-52.

3 Gross RE, Hufnagel CA. Coarctation of the aorta. Experimental studies regarding its surgical correction. $N$ Engl J Med 1945;233:287-93.

4 Reul GL, Kabbani SS, Sandiford FM, Wukasch DC, Cooley DA. Repair of coarctation of the aorta by patch graft aortoplasty. $J$ Thorac Cardiovasc Surg 1974;68:696-704.

5 Gross RE. Treatment of certain aortic coarctations by homologous grafts. Ann Surg 1951;134:753-7.

6 Morris GC, Cooley DA, DeBakey ME, Crawford ES. Coarctation of the aorta with particular emphasis upon improved techniques of surgical repair. $J$ Thorac Cardiovasc Surg 1960;40:705-11.

7 Vorsschulte K. Surgical correction of the aorta by an isthmus plastic operation. Thorax 1961;16:338-45.

8 Waldhausen JA, Nahrwold DL. Repair of coarctation of the aorta with a subclavian flap. $J$ Thorac Cardiovasc Surg 1966;51:532-3.

9 Campalani G, Firmin RK, Vaughan M, Ross DN. Surgical repair of coarctation of the aorta using the internal mammary artery as a free autogenous graft. $J$ Thorac Cardiovasc Surg 1985;90:928-31.
10 Waldhausen JA, King H, Nahrwold DL, Lurie PR, Shumaker HB. Management of coarctation in infancy. JAMA 1964;187:270-4.

11 Lawrie GM, De Bakey ME, Morris GC Jr, Crawford ES, Wagner WF, Glaeser DH. Late repair of coarctation of the descending thoracic aorta in 190 patients. Arch Surg 1981;116:1557-60.

12 National Heart Lung and Blood Institute's Task Force on Blood Pressure Control in Children. Standards for children's blood pressure. Paediatrics 1979;59:802-3.

13 Page IH. The effect of chronic constriction of the aorta on arterial blood pressure in dogs. An attempt to produce coarctation of the aorta. Am Heart J 1940; 19:218-23.

14 Srouji MN, Trusler GA. Paradoxical hypertension and the abdominal pain syndrome following resection of coarctation of the aorta. Can Med Assoc J 1965;92: 412-5.

15 Seally WC. Coarctation of the aorta and hypertension. Ann Thorac Surg 1967;3:15-28.

16 Gupta TC, Wiggers CJ. Basic haemodynamic changes produced by aortic coarctation of different degrees. Circulation 1951;3:17-31.

17 Campbell M. Natural history of coarctation of the aorta. Br Heart $J$ 1970;32:633-40.

18 Lerberg DB, Hardesty RL, Siewers RD, Zuberbuhler JR, Bahnson HT. Coarctation of the aorta in infants and children: 25 years of experience. Ann Thorac Surg 1982;33:159-70.

19 Pennington DG, Liberthson RR, Jacobs M, Scully H, Goldblatt A, Daggett WM. Critical review of experience with surgical repair of coarctation of the aorta. $J$ Thorac Cardiovasc Surg 1979;77:217-29.

20 Bergdahl L, Bjork VO, Jonasson R. Surgical correction of coarctation of the aorta. Influence of age on late results. J Thorac Cardiovasc Surg 1983;85:532-6.

21 Maron BJ, Humphries JO, Rowe RD, Mellits ED. Prognosis of surgically corrected coarctation of the aorta. A 20 year postoperative appraisal. Circulation 1973;47:119-26.

22 Clarkson PM, Nicholson MR, Barratt-Boyes BG, Neutze JM, Whitlock RM. The results after repair of coarctation of the aorta beyond infancy. A 10 to 28 year follow up with particular reference to late systemic hypertension. Am J Cardiol 1983;51:1481-8.

23 Shinebourne EA, Tam ASY, Elseed AM, et al. Coarctation of the aorta in infancy and childhood. Br Heart $J$ 1976;38:375-80.

24 Eshaghpour E, Olley PM. Recoarctation of the aorta following coarctectomy in the first year of life: a follow up study. J Paediatr 1972;80:809-14.

25 Hamilton DI, Di Eusanio G, Sandrasagra FA, Donnelly RJ. Early and late results of left sub-clavian flap aortoplasty for coarctation of the aorta in infancy. $J$ Thorac Cardiovasc Surg 1978;75:699-704.

26 Patel R, Singh SP, Abrams L, Roberts KD. Coarctation of the aorta with special reference to infants. Long term results of operation in 126 cases. Br Heart J 1977;39:1246-53.

27 Williams WG, Shindo G, Trusler GA, Dische MR, Olley PM. Results of repair of coarctation of the aorta during infancy. $J$ Thorac Cardiovasc Surg 1980;79:603-8. 
28 Beekman RH, Rocchini AP, Behrendt DM, Rosenthal A. Re-operation for coarctation of the aorta. Am J Cardiol 1981;48:1108-14.

29 Moss AJ, Adams FH, O'Loughlin BJ, Dixon WJ. The growth of the normal aorta and of the anastomotic site in infants following surgical resection of coarctation of the aorta. Circulation 1959;19:338-49.

30 Bergdahl L, Ljungqvist A. Long-term results after repair of coarctation of the aorta by patch grafting. $J$ Thorac Cardiovasc Surg 1980;80:177-81.

31 Hoffman E, Junemann A. Falsche aneurysmen nach operationen an der thorakalen aorta. Thoraxchir Vask Chir 1971;19:419-20.

32 Allen HD, Marx GR, Ovitt TW. Balloon angioplasty for coarctation: serial evaluation. J Am Coll Cardiol 1985;5:405-9.

33 Kan JS, White RI, Mitchell SE, Farmlett EJ, Donahoo JS, Gardner TJ. Treatment of restenosis of coarctation by percutaneous transluminal angioplasty. Circulation 1983;68:1087-94.

34 Lock JE, Bass JL, Amplatz K, Fuhrman BP, CastanedaZuniga W. Balloon dilatation angioplasty of aortic coarctations in infants and children. Circulation 1983;
68:109-16.

35 Cooper RS, Ritter SB, Golinko RJ. Balloon dilatation $\stackrel{\vec{\rho}}{\rightarrow}$ angioplasty: non surgical management of coarctation of the aorta. Circulation 1984;70:903-7.

36 D'Souze VJ, Velasquez S, Weesner KM, Prabhu S. क Transluminal angioplasty of aortic coarctation with a $\overrightarrow{\mathbb{D}}$ two-balloon technique. Am J Cardiol 1984;54:457.

37 de Lezo JS, Fernandez R, Sancho M, et al. Percutaneous transluminal angioplasty for aortic isthmic coarc- $\overrightarrow{0}$ tation in infancy. Am J Cardiol 1984;54:1147.

38 Lock JE. Now that we can dilate, should we? Am J Car- $\vec{\omega}$ diol 1984;54:1358.

39 Brewer LA, Fosburg RS, Mulder GA, Verska JJ. Spinal $\overrightarrow{\vec{x}}$ cord complications following surgery for coarctation of the aorta. A study of 66 cases. J Thorac Cardiovasc $\stackrel{\sim}{-}$ Surg 1972;64:368-81.

40 Lam CR, Arciniegas E. Surgical management of coarctation of the aorta with minimal collateral circulation. Ann Surg 1973;178:693-7.

41 Alexander JC Jr. Maintenance of distal aortic perfusion by a heparin-bonded shunt during repair of coarc- $\frac{}{0}$ tation of the aorta with minimal collateral circulation. Ann Thorac Surg 1981;32:304-6. 